\title{
EFFECTS IN MAN OF THE ANTICHOLINESTERASE COMPOUND SARIN (ISOPROPYL METHYL PHOSPHONOFLUORIDATE) ${ }^{1}$
}

\author{
By DAVID GROB AND JOHN C. HARVEY
}

\author{
(From the Department of Medicine, The Johns Hopkins University and Hospital, \\ Baltimore, $M d$.)
}

(Submitted for publication August 6, 1957; accepted October 31, 1957)

A number of organic esters of phosphoric acid derivatives have been synthesized which have pharmacologic effects attributable to the inhibition of cholinesterase (ChE) enzymes. The effects resemble those produced by physostigmine and neostigmine (Prostigmin ${ }^{\circledR}$ ) but are more intense and prolonged. Di-isopropyl fluorophosphate (DFP) has been studied in detail (1-4) and has been employed as a therapeutic agent in the management of abdominal distention (2), urinary retention, and glaucoma (5). Tetraethyl pyrophosphate (TEPP) (6) and octamethyl pyrophosphoramide (OMPA) (7) proved to be of some value in the management of myasthenia gravis, but have been replaced by less potent anticholinesterase compounds. Parathion, bis-(monoisopropylamino)-fluorophosphine oxide (Mipafox ${ }^{\circledR}$ ), hexaethyl tetraphosphate (HETP), and TEPP have been widely used as agricultural insecticides, and their indiscriminate dispersal has resulted in a number of instances of poisoning, some of them fatal $(8-10)$. The nerve gases are related compounds which, because of their high toxicity and physical properties, are among the most potent chemical warfare agents (11-14). One of the most important of these is sarin (isopropyl methyl phosphonofluoridate) (15), which has also been designated $\mathrm{GB}$, and has the structural formula:<smiles>CC(C)OP(C)(=O)F</smiles>

Another is tabun (dimethylamido-ethoxyphosphoryl cyanide) (16), which has been designated GA.

1 This work was supported by a contract between the Johns Hopkins University and the U. S. Army Chemical Corps, and was originally reported in Medical Division (Chemical Corps) Research Report Numbers 17 and 18, August, 1950.
In the present study the effect of sarin on human $\mathrm{ChE}$ enzymes in vitro was compared with that of tabun, TEPP, DFP, neostigmine and parathion. Sarin was administered orally to 10 normal volunteer subjects and observations were made of signs and symptoms and of changes in plasma and red blood cell cholinesterase activity, electrical activity of the brain, movement of air into and out of the lungs, and response to atropine. The effects of the intra-arterial injection and conjunctival instillation of sarin were also investigated.

\section{METHODS}

The liquid sarin employed was 90 per cent pure by chemical analysis (17), but since the compounds which constitute the remaining 10 per cent may have anticholinesterase activity, the material was regarded as 100 per cent sarin in all calculations. Solutions of sarin in water and in propylene glycol were administered daily over periods of one to four days. The concentration of these solutions $\left(4 \times 10^{-6}\right.$ to $\left.2.5 \times 10^{-4} \mathrm{M}\right)$ was confirmed by colorimetric estimation, and by determination of inhibition of plasma and red blood cell cholinesterase in vitro and of toxicity to rats. Solutions were adjusted to a $\mathrm{pH}$ of 5 to 6 , at which hydrolysis is slowest, and stored at $5^{\circ} \mathrm{C}$. for up to three days. At the end of this time there was less than five per cent decrease in the active concentration of sarin in aqueous solution, and no change in propylene glycol solution.

The cholinesterase activity of plasma (heparinized) and red blood cells was determined in duplicate or triplicate by electrometric determination of change in hydrogen ion concentration (18) before and after the administration of sarin. The standard deviation of parallel replicate determinations was four per cent for plasma cholinesterase and three per cent for the red blood cell enzyme, and five per cent for replicate determinations on separate days following storage of frozen plasma or hemolyzed red blood cells.

For the studies of anticholinesterase activity of sarin and tabun carried out in vitro, plasma (heparinized) and red blood cells were obtained from normal subjects, and skeletal muscle and brain were obtained immediately post mortem from patients who had died of diseases that did not directly involve these tissues. Cholinesterase 


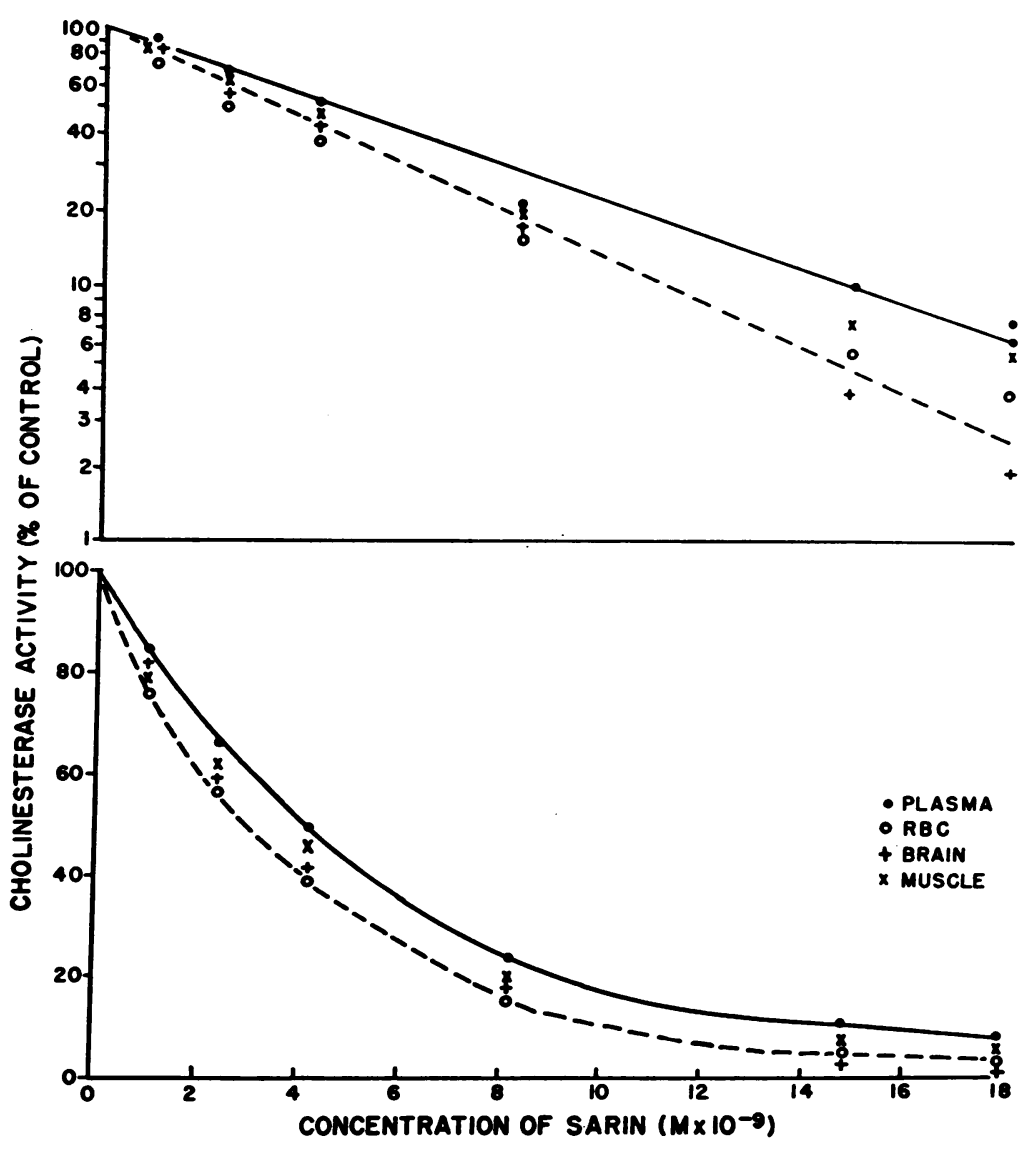

Fig. 1. Effect of Sarin on Human Plasma, Red Blood Cell, Brain, and Muscle Cholinesterase Activity IN Vitro

The same data are presented in the upper graph on a logarithmic scale, and in the lower graph on a linear scale. The concentrations of the enzyme preparations are recorded in Table I.

activity was determined in duplicate or triplicate manometrically (1). The standard deviation of parallel replicate determinations was five per cent.

\section{RESULTS}

I. Effect of sarin on the cholinesterase activity of human plasma, red blood cells, muscle and brain in vitro

\section{A. Inhibition of cholinesterase}

Plasma cholinesterase was slightly less sensitive to inhibition by sarin than the cholinesterases present in red blood cells, muscle and brain, which were approximately equally sensitive (Figure 1 and Table I). Increasing concentrations of sarin resulted in increasing inhibition of enzyme ac- tivity (Figure 1). Each increment in concentration inhibited the same fraction of cholinesterase and had a diminishing effect on the amount inhibited. The logarithm of the fraction of cholinesterase that remained active decreased linearly with increasing concentration of sarin, or, the logarithm of the reciprocal of the fraction that remained active was directly proportional to the concentration of sarin:

$$
\log \frac{\mathrm{ChE}_{1}}{\mathrm{ChE}_{0}}=-\mathrm{kS}, \quad \text { or, } \log \frac{\mathrm{ChE}_{0}}{\mathrm{ChE}_{1}}=\mathrm{kS} \text {, }
$$

where $\mathrm{ChE}_{0}$ equals cholinesterase activity just before the addition of sarin ; $\mathrm{ChE}_{1}$ equals cholinesterase activity one hour later; and $S$ equals concentration of sarin. One hour after the addition 
TABLE I

The in vitro sensitivity of human plasma, red blood cell, brain and muscle cholinesterases to inhibition of sarin, tabun, TEPP, DFP, neostigmine and parathion*

\begin{tabular}{|c|c|c|c|c|}
\hline & Plasma ChE & RBC ChE & Brain $\mathrm{ChE}$ & Muscle ChE \\
\hline $\begin{array}{l}\text { Sarin } \\
\text { Tabun } \\
\text { TEPP } \\
\text { DFP } \\
\text { Neostigmine } \\
\text { Parathion }\end{array}$ & $\begin{array}{r}4.2 \times 10^{-9} \\
1.3 \times 10^{-8} \\
5 \times 10^{-9} \\
9.5 \times 10^{-9} \\
4 \times 10^{-8} \\
1 \times 10^{-6}\end{array}$ & $\begin{array}{r}3 \times 10^{-9} \\
1.5 \times 10^{-8} \\
3.5 \times 10^{-8} \\
4 \times 10^{-7} \\
8 \times 10^{-7} \\
1.2 \times 10^{-5}\end{array}$ & $\begin{array}{r}3.3 \times 10^{-9} \\
1.5 \times 10^{-8} \\
3.2 \times 10^{-8} \\
3 \times 10^{-7} \\
4 \times 10^{-7} \\
1.3 \times 10^{-5}\end{array}$ & $\begin{array}{r}3.6 \times 10^{-9} \\
2 \times 10^{-8} \\
3.5 \times 10^{-8} \\
2.5 \times 10^{-7} \\
3 \times 10^{-7} \\
1.5 \times 10^{-5}\end{array}$ \\
\hline
\end{tabular}

* The molar concentration of each anticholinesterase agent is recorded which produced 50 per cent inhibition of the $\mathrm{ChE}$ activity of a solution or homogenate which hydrolyzed $4.8 \times 10^{-4} \mathrm{mM}$ acetylcholine bromide per hour in the absence of inhibitor. This rate of hydrolysis was produced by $51 \mathrm{mg}$. per ml. of plasma, $124 \mathrm{mg}$. per ml. of brain (cerebral cortex) homogenate, $58 \mathrm{mg}$. per ml. of muscle (psoas) homogenate, and $34 \mathrm{mg}$. per ml. of red blood cell contents. The initial concentration of acetylcholine bromide was $0.015 \mathrm{M}$. ChE and antiChE compounds were mixed 45 minutes before the addition of acetylcholine.

of sarin, cholinesterase could not be reactivated by standing, dilution or dialysis against running water.

\section{B. Comparison with other anticholinesterase com- pounds}

The inhibitory activity of sarin against the cholinesterase enzymes of the red blood cells, muscle and brain was greater than that of the other anticholinesterase compounds, being approximately 5 times that of tabun, 10 times that of TEPP (6), 100 times that of DFP (1), and 4,000 times that of parathion (19) under the conditions of the experiment (Table I). The inhibitory activity of sarin against plasma cholinesterase was approximately equal to that of TEPP, and was greater than that of the other anticholinesterase compounds. The cholinesterases of red blood cells, muscle and brain were approximately equally sensitive to inhibition by each of the compounds stud- ied. Plasma cholinesterase was slightly less sensitive than the other cholinesterases to inhibition by sarin, more sensitive to inhibition by TEPP, DFP, neostigmine and parathion, and as sensitive as the other enzymes to inhibition by tabun.

Sarin resembled tabun and DFP in combining with cholinesterase almost irreversibly during the first hour of their reaction. In contrast, the combination of TEPP or parathion with cholinesterase is slightly reversible $(6,19)$, while the combination of neostigmine with the enzyme is entirely reversible (20).

\section{Solubility of sarin in an aqueous and lipoid medium, and comparison with the other anti- cholinesterase compounds}

Aqueous solutions of each anticholinesterase compound (concentrations as in Table I) were homogenized with equal volumes of peanut oil, following which the latter was removed by centri-

TABLE II

Oral administration of sarin to ten normal subjects

\begin{tabular}{|c|c|c|c|c|c|c|c|c|}
\hline \multirow[b]{2}{*}{ Subject } & \multicolumn{2}{|c|}{$\begin{array}{c}\text { Initial dose of } \\
\text { sarin }\end{array}$} & \multicolumn{2}{|c|}{$\begin{array}{l}\% \text { Reduction of } \mathrm{ChE}^{*} \\
\text { after initial dose } \\
\end{array}$} & \multicolumn{2}{|c|}{$\begin{array}{l}\text { Total amt. of sarin } \\
\text { admn. over } 3 \text { days } \\
\end{array}$} & \multicolumn{2}{|c|}{$\begin{array}{c}\text { Maximum reduc- } \\
\text { tion of } \mathrm{ChE}^{*}\end{array}$} \\
\hline & $m g$. & $m g . / K g$. & Plasma & RBC & $m g$. & $m g . / K g$ & Plasma & RBC \\
\hline $\begin{array}{l}\text { 1. W. B. } \\
\text { 2. E. M. } \\
\text { 3. S. M. } \\
\text { 4. C. L. } \\
\text { 5. W. T. } \\
\text { 6. O. L. } \\
\text { 7. W. R. } \\
\text { 8. T. C. } \\
\text { 9. W. M. } \\
\text { 10. C. C. }\end{array}$ & $\begin{array}{l}0.030 \\
0.031 \\
0.123 \\
0.137 \\
0.472 \\
0.560 \\
0.956 \\
1.309 \\
1.540 \\
1.760\end{array}$ & $\begin{array}{l}0.0005 \\
0.005 \\
0.002 \\
0.002 \\
0.008 \\
0.008 \\
0.016 \\
0.016 \\
0.022 \\
0.022\end{array}$ & $\begin{array}{l}10 \\
10 \\
10 \\
18 \\
37 \\
32 \\
60 \\
57 \\
69 \\
69\end{array}$ & $\begin{array}{l}10 \\
10 \\
15 \\
20 \\
38 \\
46 \\
72 \\
68 \\
85 \\
72\end{array}$ & $\begin{array}{l}0.426 \\
0.428 \\
2.70 \\
3.00 \\
5.66 \\
6.72 \\
3.82 \\
7.85 \\
7.14 \\
8.36\end{array}$ & $\begin{array}{l}0.007 \\
0.007 \\
0.044 \\
0.044 \\
0.096 \\
0.096 \\
0.064 \\
0.096 \\
0.102 \\
0.102\end{array}$ & $\begin{array}{l}14 \\
29 \\
69 \\
81 \\
86 \\
81 \\
87 \\
88 \\
88 \\
84\end{array}$ & $\begin{array}{l}33 \\
27 \\
93 \\
93 \\
97 \\
98 \\
98 \\
99 \\
99 \\
99\end{array}$ \\
\hline
\end{tabular}

* ChE activity is expressed as per cent of initial activity. 
fugation and the anticholinesterase activity of the remaining aqueous solutions determined against plasma, red blood cell, brain and muscle cholinesterases (concentrations as in Table I). Sarin was more soluble in peanut oil than in water, 75 per cent being extracted from the aqueous solution. In this regard, sarin resembled DFP and parathion, of which 87 and 95 per cent were extracted, and was in contrast to TEPP and neostigmine, of which 6 and 16 per cent were extracted. Tabun was equally soluble in the two media, since 53 per cent was extracted.

\section{Effect of oral administration of sarin}

Sarin was administered orally in aqueous solution to eight normal subjects and in dilute propyl-
TABLE III

Doses of orally administered sarin that produced signs and symptoms

\begin{tabular}{|c|c|c|c|c|}
\hline \multirow{2}{*}{$\begin{array}{l}\text { Severity } \\
\text { of signs } \\
\text { and } \\
\text { symptoms }\end{array}$} & \multirow{2}{*}{$\begin{array}{c}\text { Single dose } \\
\text { (mg./Kg.) }\end{array}$} & \multicolumn{3}{|c|}{$\begin{array}{l}\text { Total dose (mg./Kg.) adminis- } \\
\text { tered in increments of } 0.008 \\
\text { to } 0.016 \mathrm{mg} . / \mathrm{Kg} \text {. at an average } \\
\text { interval of } 7.4 \text { hrs. over: }\end{array}$} \\
\hline & & $24 \mathrm{hrs}$. & $48 \mathrm{hrs}$. & $72 \mathrm{hrs}$. \\
\hline Mild & 0.022 & 0.032 & 0.060 & 0.088 \\
\hline Moderate & 0.028 & 0.046 & 0.070 & 0.102 \\
\hline
\end{tabular}

ene glycol to two others, over a 3 day period at intervals of 3 to 24 (average, 7.4) hours (Table II). Each dose was administered in 50 to 100 ml. tap water. At intervals before, during and after the period of administration of sarin, placebos

TABLE IV

Signs and symptoms following oral administration of sarin

\begin{tabular}{|c|c|c|c|}
\hline Subject & Muscarine-like & Nicotine-like & Central nervous system \\
\hline 1. W. B. & 0 & 0 & 0 \\
\hline 2. E. M. & 0 & 0 & 0 \\
\hline 3. S. M. & 0 & 0 & $\begin{array}{l}\text { Excessive dreaming, talking } \\
\text { in sleep }\end{array}$ \\
\hline 4. C. L. & $\begin{array}{l}\text { Anorexia, mild abdominal cramps, excessive } \\
\text { sweating }\end{array}$ & 0 & 0 \\
\hline 5. W. T. & $\begin{array}{l}\text { Anorexia, nausea, abdominal cramps, sweating, } \\
\text { tightness in throat and chest, epigastric and } \\
\text { substernal tightness with "heartburn" and eruc- } \\
\text { tation }\end{array}$ & Easy fatigue & $\begin{array}{l}\text { Giddiness, tension, anxiety, } \\
\text { excessive dreaming with } \\
\text { nightmares }\end{array}$ \\
\hline 6. O. L. & $\begin{array}{l}\text { Anorexia, nausea, abdominal cramps, tightness } \\
\text { in chest, epigastric and substernal tightness, } \\
\text { bradycardia }\end{array}$ & Easy fatigue & 0 \\
\hline 7. W. R. & $\begin{array}{l}\text { Same as W. T., but tightness in chest more } \\
\text { marked, with audible wheezing, prolonged ex- } \\
\text { piration and subjective dyspnea }\end{array}$ & Easy fatigue & Headache, anxiety, tremor \\
\hline 8. T. C. & $\begin{array}{l}\text { Anorexia, tightness in chest, epigastric and sub- } \\
\text { sternal tightness, loose stools, excessive sweat- } \\
\text { ing, urinary frequency, subjective dyspnea with } \\
\text { prolongation of expiratory phase }\end{array}$ & $\begin{array}{l}\text { Easy fatigue, } \\
\text { weakness, muscle } \\
\text { twitching }\end{array}$ & $\begin{array}{l}\text { Giddiness, insomnia, with } \\
\text { excessive dreaming, tension, } \\
\text { anxiety, jitteriness, head- } \\
\text { ache, withdrawal and mod- } \\
\text { erate depression, restless- } \\
\text { ness and emotional lability, } \\
\text { tremor }\end{array}$ \\
\hline 9. W. M. & $\begin{array}{l}\text { Anorexia, nausea, abdominal cramps, tightness } \\
\text { and mild pain in chest with wheezing, prolonged } \\
\text { expiration and subjective dyspnea, epigastric } \\
\text { and substernal tightness and pain, loose stools }\end{array}$ & $\begin{array}{l}\text { Easy fatigue, } \\
\text { weakness }\end{array}$ & $\begin{array}{l}\text { Insomnia, tension, jitteri- } \\
\text { ness, headache, giddiness }\end{array}$ \\
\hline 10. C. C. & $\begin{array}{l}\text { Anorexia, nausea, vomiting, abdominal cramps, } \\
\text { tightness and discomfort in chest with wheezing } \\
\text { respiration, prolonged expiration and some dysp- } \\
\text { nea, epigastric and substernal tightness and dis- } \\
\text { comfort, eructation, sweating, salivation, lacri- } \\
\text { mation, tenesmus and urgent loose stools }\end{array}$ & $\begin{array}{l}\text { Easy fatigue, } \\
\text { weakness, muscle } \\
\text { twitching and } \\
\text { fasciculations, } \\
\text { pallor }\end{array}$ & $\begin{array}{l}\text { Insomnia, excessive dream- } \\
\text { ing, withdrawal, depression }\end{array}$ \\
\hline
\end{tabular}


DAVID GROB AND JOHN C. HARVEY

TABLE V

Signs and symptoms produced by sarin

\begin{tabular}{|c|c|c|}
\hline \multirow[b]{2}{*}{ Site of action } & \multicolumn{2}{|c|}{ Local effects } \\
\hline & After conjunctival exposure & Additional effects of exposure to vapor (13) \\
\hline \multicolumn{3}{|l|}{ 1. Muscarine-like } \\
\hline Pupils & $\begin{array}{l}\text { Miosis, marked or maximal, occasion- } \\
\text { ally unequal }\end{array}$ & \\
\hline Ciliary body & $\begin{array}{l}\text { Frontal headache, eye pain on focus- } \\
\text { sing, slight dimness of vision, occa- } \\
\text { sional nausea and vomiting }\end{array}$ & \\
\hline \multirow[t]{3}{*}{$\begin{array}{l}\text { Conjunctivas } \\
\text { Nasal mucous membranes } \\
\text { Bronchial tree }\end{array}$} & Hyperemia & $\begin{array}{l}\text { Rhinorrhea, hyperemia } \\
\text { Tightness in chest, occasionally with } \\
\text { prolonged wheezing expiration sug- } \\
\text { gestive of bronchoconstriction or } \\
\text { increased secretion }\end{array}$ \\
\hline & \multicolumn{2}{|c|}{ Systemic effects } \\
\hline & After oral administration & $\begin{array}{l}\text { Additional effects of absorption } \\
\text { by any route (13) }\end{array}$ \\
\hline Gastrointestinal & $\begin{array}{l}\text { Anorexia, nausea, vomiting, abdomi- } \\
\text { nal cramps, epigastric and subster- } \\
\text { nal tightness (? cardiospasm) with } \\
\text { "heartburn" and eructation, diar- } \\
\text { rhea, tenesmus }\end{array}$ & Involuntary defecation \\
\hline $\begin{array}{l}\text { Sweat glands } \\
\text { Salivary glands } \\
\text { Lacrimal glands } \\
\text { Heart }\end{array}$ & $\begin{array}{l}\text { Increased sweating } \\
\text { Increased salivation } \\
\text { Increased lacrimation }\end{array}$ & Slight bradycardia \\
\hline Bronchial tree & $\begin{array}{l}\text { Tightness in chest, with prolonged } \\
\text { wheezing expiration suggestive of } \\
\text { bronchoconstriction or increased } \\
\text { secretion, dyspnea, slight pain in } \\
\text { chest }\end{array}$ & $\begin{array}{l}\text { Increased bronchial secretion, pulmo- } \\
\text { nary edema, with cyanosis }\end{array}$ \\
\hline $\begin{array}{l}\text { Pupils } \\
\text { Ciliary body }\end{array}$ & $\operatorname{coses}$ & $\begin{array}{l}\text { Miosis (variable) } \\
\text { Blurring of vision }\end{array}$ \\
\hline Bladder & Frequency & Involuntary micturition \\
\hline \multicolumn{3}{|l|}{ 2. Nicotine-like } \\
\hline Striated muscle & $\begin{array}{l}\text { Easy fatigue, mild weakness, muscu- } \\
\text { lar twitching, fasciculations, gener- } \\
\text { alized weakness }\end{array}$ & $\begin{array}{l}\text { Cramps, weakness of muscles of res- } \\
\text { piration, with dyspnea }\end{array}$ \\
\hline Sympathetic ganglia & $\begin{array}{l}\text { Pallor, occasional elevation of blood } \\
\text { pressure }\end{array}$ & \\
\hline 3.ICentral nervous system & $\begin{array}{l}\text { Giddiness, excessive dreaming, insom- } \\
\text { nia, nightmares, tension, anxiety, } \\
\text { jitteriness, restlessness, emotional } \\
\text { lability, headache, tremor, with- } \\
\text { drawal and depression, reduction } \\
\text { of voltage of EEG, bursts of slow } \\
\text { waves of elevated voltage in EEG, } \\
\text { especially on overventilation }\end{array}$ & $\begin{array}{l}\text { Drowsiness, difficulty concentrating, } \\
\text { slowness of recall, confusion, pares- } \\
\text { thesias, slurred speech, ataxia, gen- } \\
\text { eralized weakness, coma, with ab- } \\
\text { sence of reflexes, Cheyne-Stokes } \\
\text { respirations, convulsions, depres- } \\
\text { sion of respiratory and circulatory } \\
\text { centers }\end{array}$ \\
\hline
\end{tabular}

of water and of dilute propylene glycol were administered.

\section{A. General systemic effects}

Taste. Aqueous solutions of sarin had no taste, while solutions in dilute propylene glycol had the taste of the solvent. Except for this difference, the effects of the two solutions were the same.
The highest concentration of sarin administered was $0.035 \mathrm{mg}$. per $\mathrm{ml}$., in a $50 \mathrm{ml}$. amount.

Dose that produced symptoms. A single dose of $0.022 \mathrm{mg}$. per $\mathrm{Kg}$. produced mild symptoms, and an additional $0.008 \mathrm{mg}$. per $\mathrm{Kg}$. administered within eight hours resulted in moderate symptoms. The total doses required to produce symptoms when sarin was administered over 24 to 72 hour periods 
are recorded in Table III. There was a narrow margin between the doses which produced mild symptoms and those which produced moderately severe symptoms.

Time course of symptoms and occurrence of cumulative effects. Symptoms began 20 to 60 minutes (average, 40 minutes) after the oral administration of sarin. Mild symptoms lasted for 10 minutes to 6 hours (average, 1 hour). Moderately severe symptoms lasted 5 to 24 hours. Following the disappearance of symptoms, there was increased susceptibility to the effects of sarin administered within 24 hours after the last dose. During this period, the upper limit of which was not determined, symptoms could be elicited by 0.008 to $0.016 \mathrm{mg}$. per $\mathrm{Kg}$., doses which produced no symptoms when administered for the first time. The size of the dose necessary to produce a recurrence of symptoms, and the severity of these symptoms, varied inversely with the interval between doses. Thus, $0.008 \mathrm{mg}$. per $\mathrm{Kg}$., administered at intervals of eight hours, produced symptoms after the fourth dose. These symptoms disappeared, but recurred with slightly greater severity after each subsequent dose. When the interval was greater, a larger dose was necessary to produce a recurrence of symptoms. Small divided doses of sarin totalling $0.03 \mathrm{mg}$. per $\mathrm{Kg}$. per day which were insufficient to produce symptoms on the first day resulted in mild symptoms on the second and third days of administration, while larger divided doses totalling $0.04 \mathrm{mg}$. per $\mathrm{Kg}$. per day produced more striking evidence of cumula- tion, as manifested by mild symptoms on the first day and severe symptoms on the third.

Muscarine-like signs and symptoms. The earliest symptoms to appear were usually anorexia, nausea, epigastric and substernal "tightness" (probably due to cardiospasm) with "heartburn" and eructation, and "tightness" in the chest (Tables IV and V). With larger doses of sarin, or repeated administration of small doses, there appeared abdominal cramps, vomiting, diarrhea, tenesmus, increased sweating and decreased skin resistance, increased salivation and lacrimation, slight bradycardia, pallor, urinary frequency, mild dyspnea with occasional wheezing, prolongation of expiration, and pain referred to the lower thoracic cage. Pupil size and blood pressure were not significantly changed (Table VI), except for an increase in systolic pressure of $35 \mathrm{~mm}$. $\mathrm{Hg}$ in the subject with most marked symptoms. When respiratory symptoms were present, spirometric recording usually demonstrated a slight to moderate reduction in vital capacity and in the rate of movement of air into and out of the lungs, attributable to either bronchoconstriction or increased bronchial secretion. There was definite variation in the susceptibility of different subjects to respiratory symptoms. The subject in whom respiratory manifestations were most pronounced (W. R.) had a history of frequent upper respiratory tract infections which were at times associated with symptoms suggestive of mild asthma.

Central nervous system signs and symptoms. Following the earliest muscarine-like symptoms

TABLE VI

Effect of oral administration of sarin on cardiac rate, pupil size, blood pressure, and skin resistance, and on response to atropine*

\begin{tabular}{lccc}
\hline & $\begin{array}{c}\text { Before admin. } \\
\text { of sarin }\end{array}$ & $\begin{array}{c}\text { During symptoms } \\
\text { due to sarin }\end{array}$ & $\begin{array}{c}\text { 12 hours after } \\
\text { last dose of sarin }\end{array}$ \\
\hline Cardiac rate (per minute) & 81 & 69 & 75 \\
Pupil size (mm.) & 6.1 & 4.8 & 5.5 \\
Blood pressure (mg. Hg) & $124 / 82$ & $131 / 75$ & $122 / 80$ \\
Skin resistance Palms (ohms) & 230,000 & 86,000 & 260,000 \\
$\quad$ Dorsum of hands & $1,350,000$ & 900,000 & $1,500,000$ \\
Effect of atropine sulfate (1 mg. I.V.) on: & & & +25 \\
Cardiac rate (per minute) & +30 & +18 & +1.2 \\
Pupil size (mm.) & +1.5 & +0.5 & + \\
Dryness of mouth & ++ & $+650,000$ \\
$\quad$ Skin resistance Palms (ohms) & $+860,000$ & $+300,000$ & $+3,500,000$ \\
\hline
\end{tabular}

* Average values obtained under standard conditions in the eight subjects who had symptoms following sarin. 
there appeared tension, anxiety, jitteriness, restlessness, emotional lability, giddiness, and insomnia with excessive dreaming and occasionally nightmares. With larger doses of sarin, or repeated administration of small doses, there appeared headache, tremor, withdrawal, and mild or moderate depression. Following small doses of sarin which did not cause symptoms there was no change in the electroencephalogram. With the appearance of the mildest symptoms there was noted a slight, but definite diminution in the voltage of the electroencephalogram, which in some subjects was more noticeable in the left than in the right hemisphere, especially in the occipital leads. When moderate symptoms were present, even though intermittently, there appeared in the electroencephalogram more irregularities in rhythm, variation in potential, and intermittent bursts of abnormal waves similar to those seen in patients with epilepsy $(12,13)$. These consisted of slow waves (two and one-half to six per second) of elevated voltage ( 70 to $150 \mathrm{mV}$.), usually most marked in the frontal leads. They were usually not striking prior to hyperventilation. In general, more striking electroencephalographic changes occurred in those subjects who showed greater lability of pattern (though within the limits of normal) in their control records than in those who had very regular patterns of low voltage. Following the cessation of sarin administration, the electroencephalographic changes diminished, but could be detected for 4 to 18 days after the disappearance of symptoms.

Nicotine-like signs and symptoms. All the subjects who had muscarine-like and central nervous system symptoms also had some increased fatigability, and three had mild generalized weakness, especially after exertion. Two had some involuntary muscular twitching and fasciculations. One developed moderate pallor.

Effect of atropine on symptoms due to sarin. The intravenous administration of atropine sulfate (1 mg.) was invariably followed by prompt relief of all the muscarine-like symptoms due to sarin and by an increased feeling of well-being. There was less striking improvement in the central nervous system symptoms, and usually a decrease in the voltage of the electroencephalogram (more than after atropine alone), a decrease in the irregularities of frequency and potential, and a decrease in the frequency of appearance of slow waves of elevated voltage. The slow waves did not entirely disappear; they would occur after a longer period of hyperventilation than was required to bring them out prior to the administration of atropine.

Effect of sarin on the action of atropine. In the presence of moderately severe symptoms due to sarin, there was reduced susceptibility to the action of atropine, as indicated by the effect of intravenous administration of $1 \mathrm{mg}$. of this drug on cardiac rate, pupil size, dryness of mouth, and skin resistance (Table VI). Following the disappearance of symptoms due to sarin, the response to atropine returned, and was only slightly less than prior to sarin administration.

Effect of inhaled tobacco smoke. The casual smoking of one or two cigarettes was usually promptly followed by an increase in the gastrointestinal and respiratory symptoms. In one subject, spirometric recording revealed a further decrease in the vital capacity and in the rate of movement of air into and out of the lungs.

\section{B. Effect on plasma and red blood cell cholines- terase activity}

Prior to sarin administration the cholinesterase activity of each subject was in the normal range: for plasma the range was 0.85 to $1.26 \Delta \mathrm{pH}$ per hour, and the mean, standard deviation, and standard error were $1.02,0.15$, and $0.05 \Delta \mathrm{pH}$ per hour, respectively; for red blood cells the range was 0.55 to $0.96 \Delta \mathrm{pH}$ per hour, and the mean, S.D.,

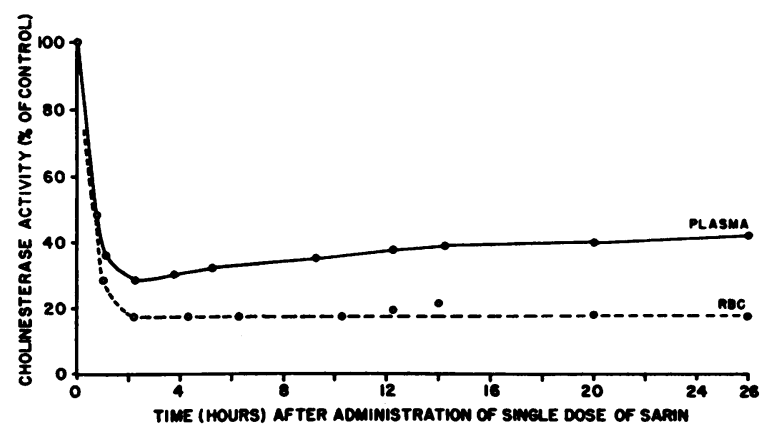

Fig. 2. Depression of Plasma and Red Blood Cell Cholinesterase Activity After a Single Oral Dose of Sarin, and Restoration During the First Day

Average values obtained in eight subjects. The average dose of sarin was $0.012 \mathrm{mg}$. per $\mathrm{Kg}$. 


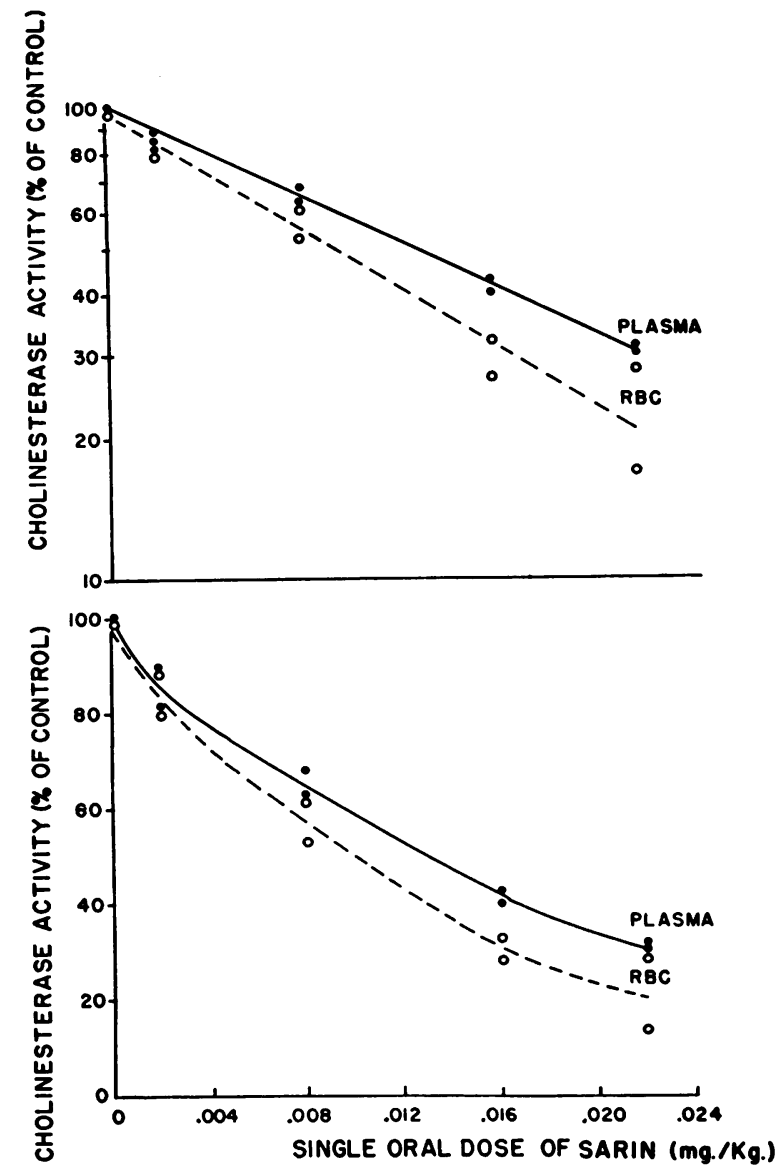

Fig. 3. Relation Between the Size of a Single Oral Dose of Sarin and the Resulting Depression of Plasma and Red Blood Cell Cholinesterase ACTIVITY

The same data are presented in the upper graph on a logarithmic scale, and in the lower graph on a linear scale.

and S.E., $0.72,0.13$, and $0.04 \Delta \mathrm{pH}$ per hour, respectively.

Effect of a single dose. The oral administration of from 0.002 to $0.022 \mathrm{mg}$. per $\mathrm{Kg}$. of sarin resulted in from 15 to 75 per cent reduction in plasma and red blood cell cholinesterase activity. Maximum depression occurred in one to two hours (Figure 2). The degree of depression of the cholinesterase activity of the red blood cells was slightly greater than that of the plasma, paralleling the relative sensitivity of these enzymes to sarin in vitro. The dose-effect relationship (Figure 3 ) was similar to that found when varying concentrations of sarin were added to cholinesterase preparations in vitro (Figure 1). Each increment in dose inhibited the same fraction of cholinesterase, and had a diminishing effect on the amount inhibited. The logarithm of the fraction of cholinesterase that remained active two hours after the administration of sarin $\left(\mathrm{ChE}_{1} / \mathrm{ChE}_{0}\right)$ decreased linearly with increasing dose of sarin $(\mathrm{S})$, or, the logarithm of the reciprocal of the fraction that remained active was directly proportional to the dose.

Effect of repeated doses. Repeated doses administered orally at intervals of 3 to 24 (average, 7.4) hours over a period of 3 to 3.5 days, in total dose of up to $0.102 \mathrm{mg}$. per $\mathrm{Kg}$., resulted in progressive diminution in the cholinesterase activity of the plasma to near 15 per cent of original activity (Table II and Figure 4). The intervals between doses of sarin were usually long enough for some restoration of plasma cholinesterase activity to take place (Figure 4), while that of the red blood cells was not appreciably restored during these intervals. This is believed to account for the progressively greater depression of red blood cell than of plasma cholinesterase activity.

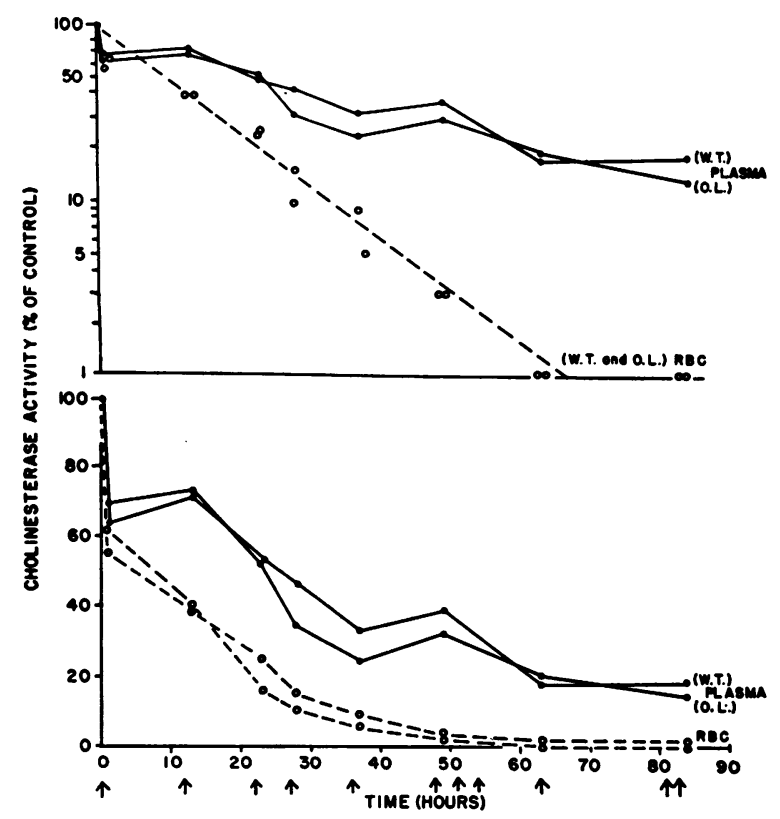

Fig. 4. Effect of the Repeated Oral Administration of Sarin on Plasma and Red Blood Cell ChoLiNesterase Activity of Two Subjects

The upper graph represents the same data plotted on a logarithmic scale. Each arrow represents the oral administration of $0.008 \mathrm{mg}$. per $\mathrm{Kg}$. of sarin. 


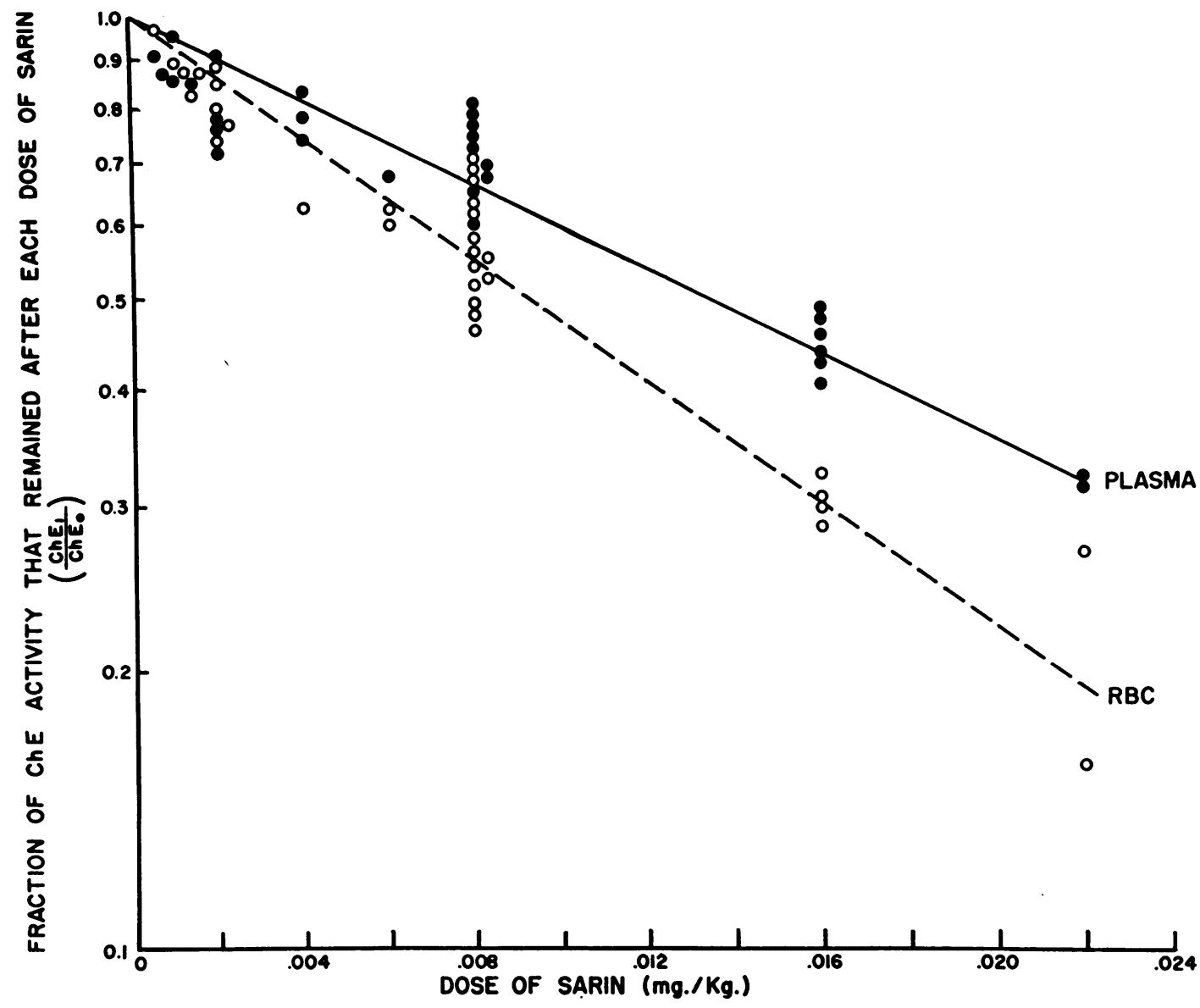

Fig. 5. Effect on Plasma and Red Blood Cell Cholinesterase Activity of Repeated Doses of Sarin Administered at Various Levels of Activity

$\mathrm{ChE}_{0}$ is the enzyme activity at the time of administration of any dose of sarin, and $\mathrm{ChE}_{1}$ the activity two hours after administration.

When sarin was administered in repeated doses the same relationship between the dose of sarin and the resulting depression of cholinesterase activity applied as following a single dose; i.e., each increment in dose inhibited the same fraction of enzyme, and the logarithm of the fraction that remained active decreased linearly with increasing dose, regardless of the initial level of activity (Figure 5). When the repeated doses of sarin were of constant size, the fraction of cholinesterase that remained active after each dose, and hence the fraction inhibited by each dose, were constant and were independent of the level of activity at the time each dose was administered (Figure 6):

$$
\frac{\mathrm{ChE}_{1}}{\mathrm{ChE}_{0}}=\mathrm{k} \text {, and } \frac{\mathrm{ChE}_{0}-\mathrm{ChE}_{1}}{\mathrm{ChE}_{0}}=1-\mathrm{k} \text {, }
$$

where $\mathrm{ChE}_{0}$ equals cholinesterase activity just before the administration of each dose of sarin, and $\mathrm{ChE}_{1}$ equals cholinesterase activity two hours after each dose. In contrast, the amount of cholinesterase inhibited by each successive dose of sarin $\left(\mathrm{ChE}_{0}-\mathrm{ChE}_{1}\right)$ decreased progressively, as it was proportional to the activity at the time the dose was administered $\left(\mathrm{ChE}_{0}\right)$ (Figure 4).

Since the restoration of red blood cell cholinesterase activity during the interval between doses of sarin was very slight, the effect of repeated doses of sarin on this enzyme was almost entirely cumulative until the enzyme was depressed below approximately three per cent of the original activity. The logarithm of the fraction of red blood cell cholinesterase that remained active at any time 


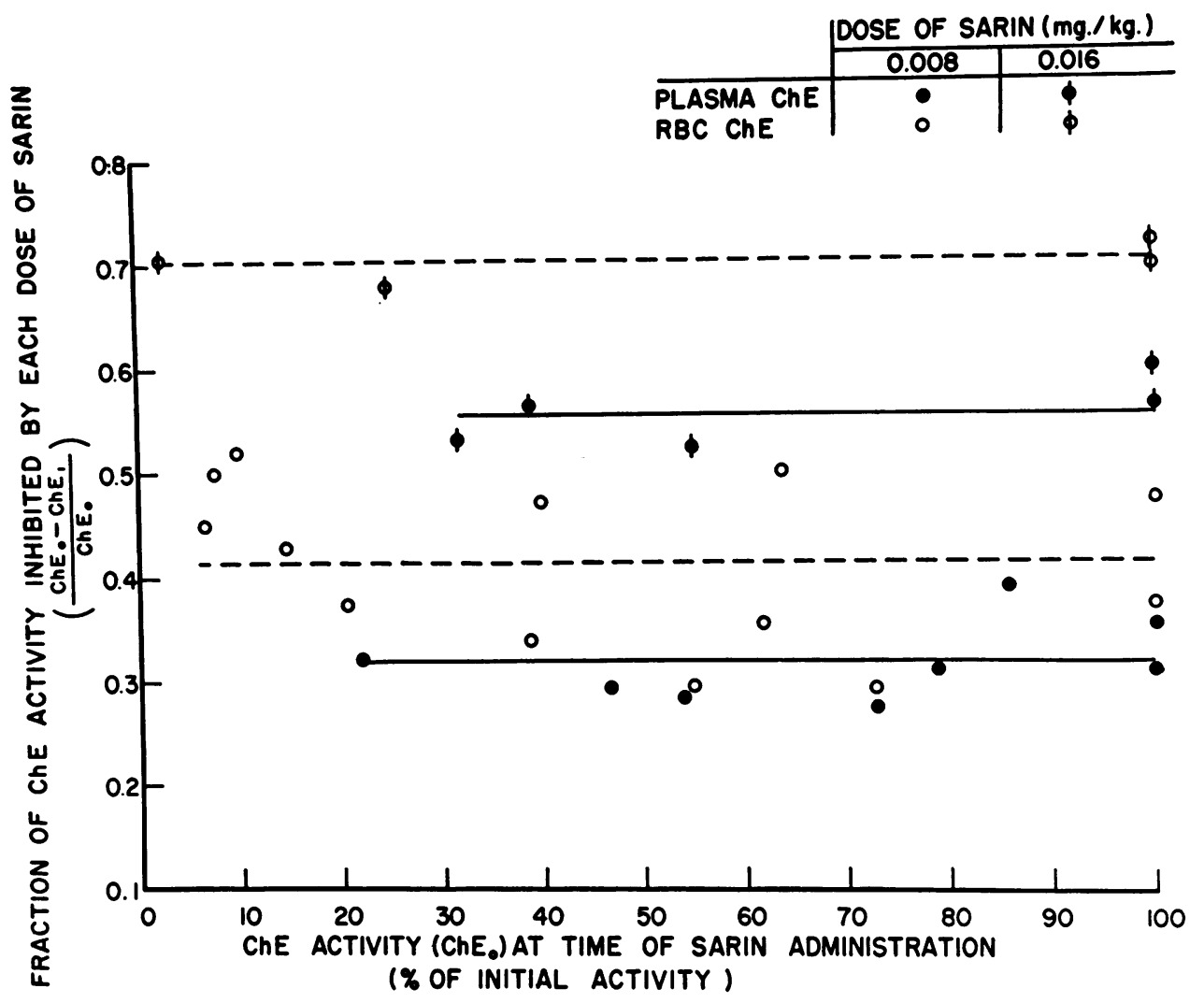

Fig. 6. Effect on Plasma and Red Blood Cell Cholinesterase Activity of Two Different Doses of Sarin Administered Repeatedly at Various Levels of Activity

$\mathrm{ChE}_{0}$ is the enzyme activity at the time of administration of any dose of sarin, and $\mathrm{ChE}_{1}$ the activity two hours after administration.

during the three day period of administration decreased linearly with the total amount of sarin that had been administered up to that time, until the activity of the enzyme was reduced below three per cent of the original value (Figure 7). At this low level of activity the slow restoration of enzyme activity between doses of sarin became significant, as did technical errors in the determination. During the three day period of administration the effect of repeated doses of sarin on red blood cell cholinesterase (Figure 7) was approximately the same as the effect of equal single doses (Figure 3 and its extrapolation in Figure 8), until the activity was depressed to the point where the daily rate of restoration became significant.

\section{Rate of restoration of plasma and red blood cell cholinesterase activity}

Following the oral administration of sarin, maximum depression of plasma and red blood cell cholinesterase activity occurred within one to two hours. After depression to near zero activity, plasma cholinesterase was restored at an average rate of approximately 4 per cent of original activity during the first 3 hours, 7 per cent during the first 24 hours (Figure 2). The rate of restoration of the plasma enzyme was maximal during the first 24 hours, and was approximately 8 per cent of original activity on the second day, 6 per cent on the third, 5 per cent on the fourth, 4 per cent on the fifth and sixth, 3 per cent per day through the ninth, 2 per cent per day through the sixteenth day, and 1 per cent per day after that time until the activity returned to its original level at the end of about 40 days (Figure 9).

Following depression of red blood cell cholinesterase to near zero, the activity of this enzyme was restored at a rate of approximately 1.1 per cent of original activity per day, over a period of 3 months. This rate was constant, with the pos- 


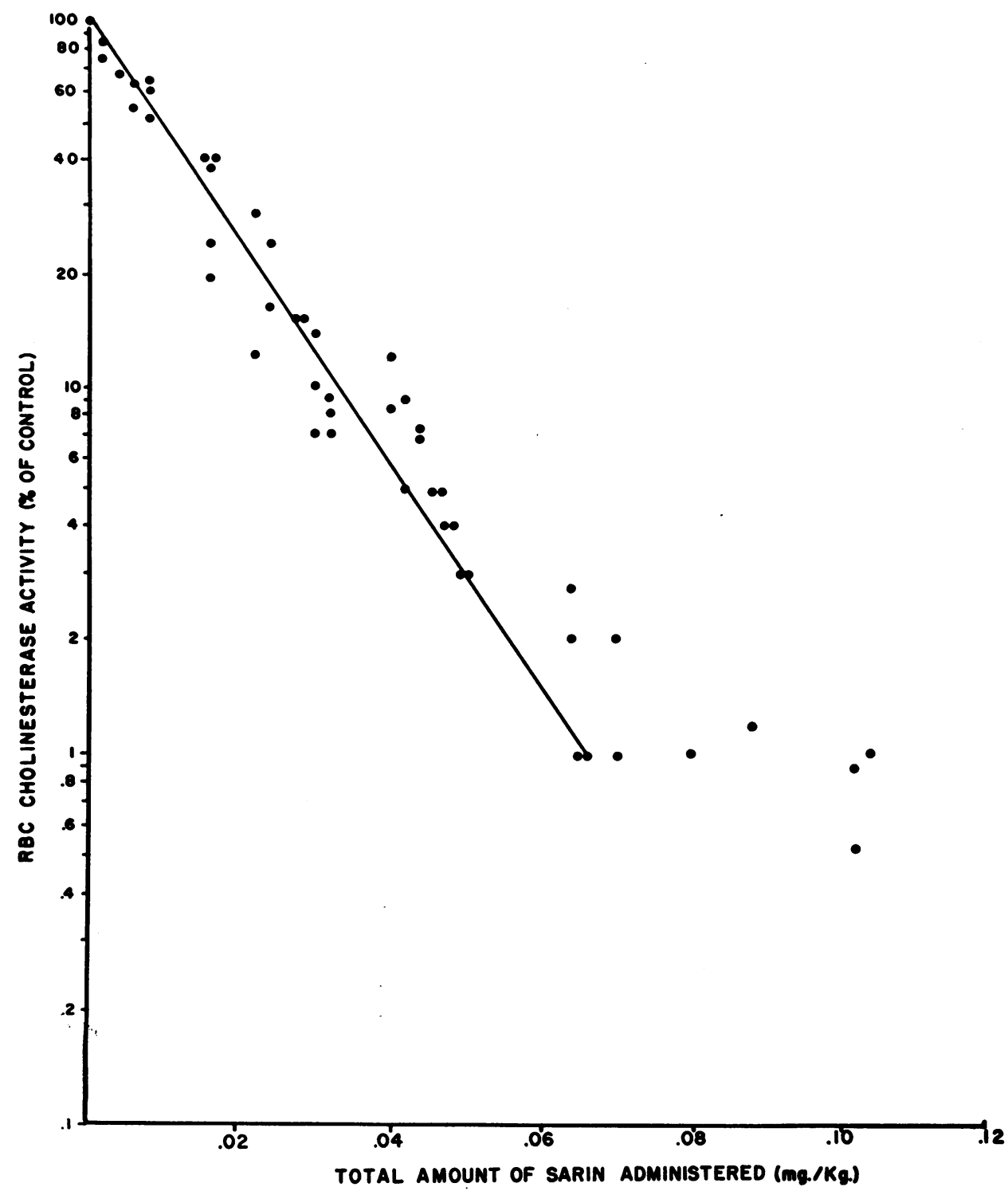

Fig. 7. Effect of the Repeated Oral Administration of Sarin on Red Blood Cell Cholinesterase Activity

The cholinesterase activity and total dose of sarin are recorded after each of the several doses that were administered to 10 subjects.

sible exception of the first day, when the increase in red blood cell enzyme activity may have been slightly greater (1.7 per cent of original activity).

Following less marked depression of plasma and red blood cell cholinesterases, the daily rates of restoration of enzyme activity were less, but the times required for complete restoration ( 40 and 92 days) were the same.

The rate of restoration of plasma cholinesterase activity was increased transiently by the intra- venous administration of plasma or whole blood, and red blood cell cholinesterase activity by whole blood, but this neither ameliorated nor prevented symptoms due to sarin.

When plasma and red blood cells were withdrawn from subjects who had received sarin and allowed to stand or dialyze at 0,5 or $24^{\circ} \mathrm{C}$. for several weeks, no restoration of cholinesterase activity could be demonstrated, indicating irreversible inactivation of these enzymes. 


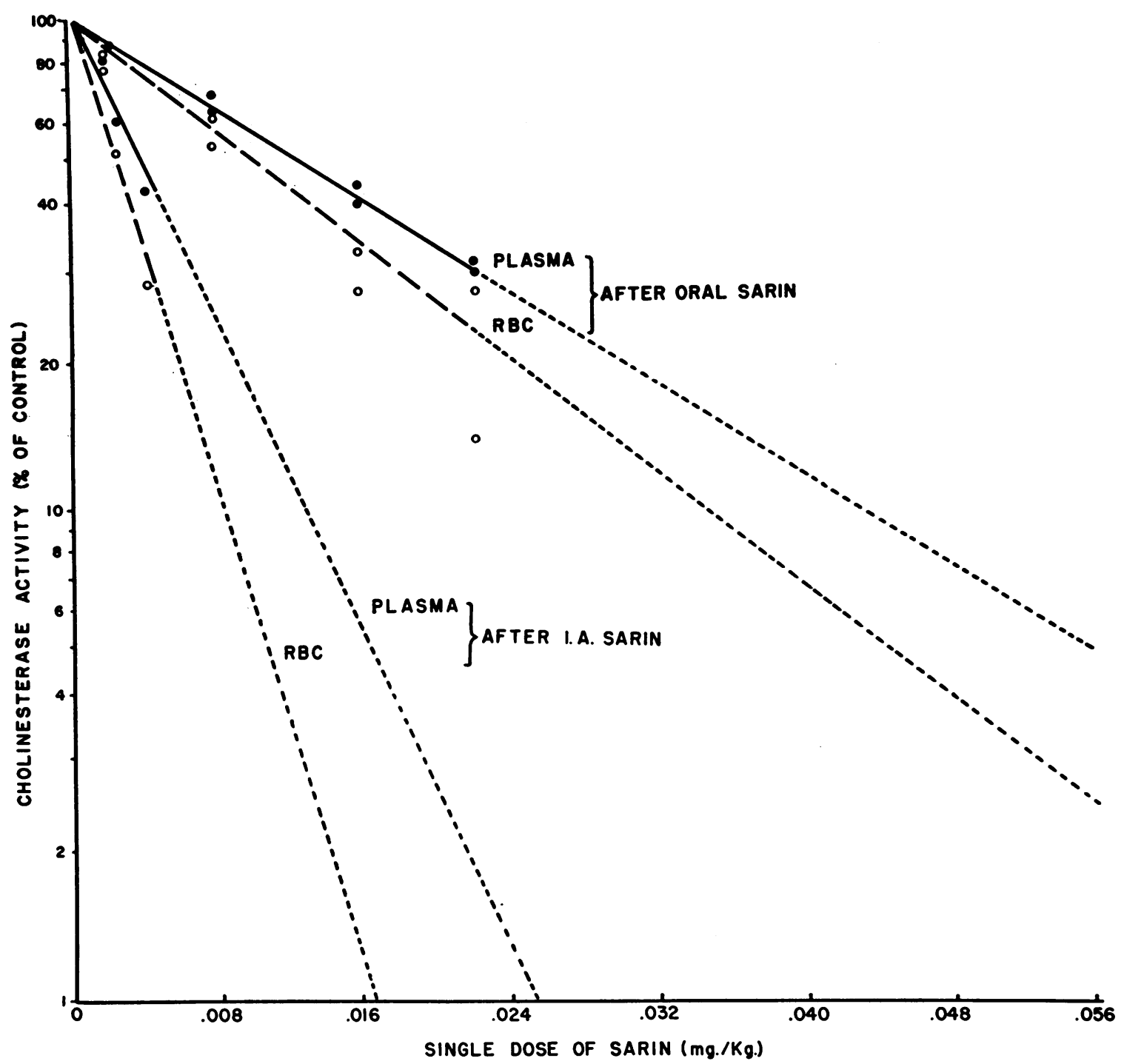

Fig. 8. Comparison Between the Effects of Single Doses of Orally and Intra-ARterially Administered Sarin on Plasma and Red Blood Cell Cholinesterase Activity

The dotted lines represent extrapolation from data.

\section{Relation of symptoms to plasma and red blood cell cholinesterase activity}

Following a single oral dose of sarin, symptoms usually began coincident with the depression of plasma and red blood cell cholinesterase activity to approximately 34 and 22 per cent of original activity. Following repeated doses there was no correlation between the onset of symptoms and the precise level of activity of the plasma and red blood cell enzymes, except that this was depressed below these values. The cholinesterase activity of the red blood cells could be gradually depressed to near zero by repeated doses administered over a period of several days without symptoms necessarily ensuing, or without any relation to the symptoms that occurred. Symptoms usually disappeared before any restoration of red blood cell cholinesterase occurred, and after little or no restoration of the plasma enzyme.

E. Absence of other effects of sarin than those attributable to the inhibition of cholinesterase enzymes

There was no change in the hematocrit, hemoglobin, red cell count, white blood count, differ- 


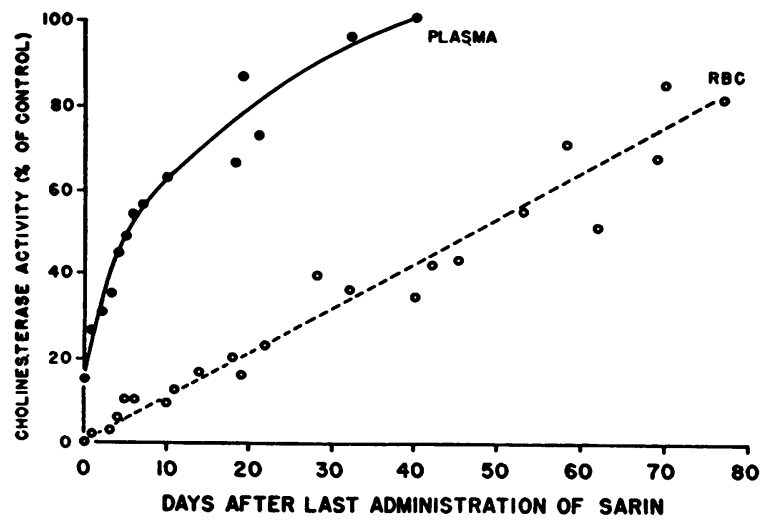

Fig. 9. Rate of Restoration of Plasma and Red Blood Cell Cholinesterase Activity After Cessation of Sarin Administration

Average values obtained in 10 subjects.

ential formula, number of circulating eosinophils, sedimentation rate, clot retraction time, blood nonprotein nitrogen, fasting blood sugar, or serum chloride, carbon dioxide combining power, calcium, phosphorus, cholesterol, uric acid, alkaline phosphatase, bilirubin, albumin and globulin. The blood coagulation time increased slightly, from a mean of 7 minutes to 13 minutes. The following tests of hepatic and renal function remained normal: thymol turbidity, cephalin flocculation, phenolsulphonphthalein excretion and urinalysis. The electrocardiogram, chest X-ray, and basal metabolic rate were also unchanged, and no occult blood was detected in the stools. The lack of effect of sarin on the fasting blood sugar, white blood count and number of circulating eosinophils, and the slight effect on blood pressure, indicate that the amounts of sarin that were administered did not cause any appreciable adrenalin release as a result of stimulation of the preganglionic autonomic nerve endings in the adrenal medulla.

\section{Effect of intra-arterial administration of sarin}

The injection of 0.003 and $0.005 \mathrm{mg}$. per $\mathrm{Kg}$. of sarin into the brachial artery of two subjects produced local effects in the injected extremity and systemic effects. The local effects included profuse sweating (despite the prior intramuscular administration of $2.25 \mathrm{mg}$. atropine sulfate), reduction of grip strength by about 50 per cent, and fasciculations which appeared after exercise. The systemic effects were similar to those that were observed after the oral administration of sarin and included anorexia, nausea, generalized sweating (despite the prior administration of atropine), giddiness (especially on standing), some generalized weakness, twitching of leg muscles, insomnia and nightmares. The sweating lasted for 12 hours. Electroencephalograms obtained two and four days after the administration of sarin revealed a slight overall decrease in voltage and intermittent bursts of slow waves, occurring at a frequency of one and one-half to two and one-half per second. Plasma cholinesterase was reduced to 61 and 42 per cent of original activity, and red blood cell cholinesterase to 52 and 28 per cent of original activity (Figure 8). These changes were similar to those which followed the oral administration of approximately three and one-half times as much sarin. This ratio is the same as for DFP (1-4) and TEPP (6).

\section{Effect of conjunctival instillation of sarin}

The instillation of sarin (in aqueous solution or normal saline) into the conjunctival sac resulted in striking and very prolonged miosis of the treated eye. The lowest concentration of sarin that produced definite and persistent miosis when one drop $(0.03 \mathrm{ml}$.) was instilled was $0.01 \mathrm{mg}$. per $\mathrm{ml}$. This amount of sarin $(0.0003 \mathrm{mg}$.) produced within 10 minutes local miosis which was marked, though not quite maximal. There were no subjective manifestations. The miosis gradually diminished over a period of 60 hours. The instillation of one drop $(0.03 \mathrm{ml}$.) of a solution containing $0.03 \mathrm{mg}$. per $\mathrm{ml}$. of sarin resulted within 10 minutes in miosis which was nearly maximal. This extreme miosis persisted for several minutes and was followed by submaximal pupillary constriction which remained severe for 72 hours, and disappeared after about 90 hours. There were mild local symptoms of "pressure" in the treated eye and the sensation that the eye "felt smaller and had sunk back into the head." These local effects of sarin were not associated with any change in plasma or red blood cell cholinesterase activity. They were not appreciably influenced by the intravenous administration of $1 \mathrm{mg}$. atropine sulfate, but were ameliorated by the repeated conjunctival instillation of one per cent atropine or two per cent homatropine. 
DISCUSSION

The effects observed after administration of sarin, and those which have occurred after more marked exposure than in this study (13) (Table $\mathrm{V})$, are similar to the effects of other organic phosphate anticholinesterase compounds, such as DFP (1), TEPP (6) and parathion (8). They are entirely attributable to the inhibition of cholinesterase enzymes in the effector tissues and resultant local accumulation of excessive concentrations of acetylcholine wherever this compound is normally liberated: at the endings of the parasympathetic nerves to the smooth muscle of the iris, ciliary body, bronchial tree, gastrointestinal tract, bladder, and blood vessels, to the secretory glands of the respiratory tract and to cardiac muscle, and of sympathetic nerves to the sweat glands (resulting in "muscarine-like" signs and symptoms); at the endings of motor nerves to voluntary muscle and in the autonomic ganglia (resulting in "nicotine-like" signs and symptoms); and in the central nervous system. The effects of sarin, like those of the other organic phosphate anticholinesterase compounds, can be classified as local or systemic. Local effects on the smooth muscle of the eye and on the conjunctival blood vessels occurred after local ocular exposure, and local effects on the smooth muscle and secretory glands of the respiratory tract occur after inhalation of sarin vapor (13). Systemic effects follow sufficient absorption by any route. Since gastrointestinal symptoms were more pronounced after ingestion of sarin than after comparable absorption by other routes (13), it is possible that these may be the result of local as well as systemic action.

The effects of systemic absorption of sarin on the eye were negligible, in the doses administered, and even more marked systemic exposure has minimal effect on the eye in the absence of local exposure (13). The effect of systemic absorption on the smooth muscle and secretory glands of the respiratory tract, as indicated by symptoms and signs compatible with bronchoconstriction or increased bronchial secretion, were slight except for one subject who had a history suggestive of mild asthma. More marked local or systemic exposure may result in a considerable increase in bronchial secretion, but bronchoconstriction has not been prominent in man (13), in contrast to most experimental animals $(15,16)$. Systemic absorption of sarin did not produce evidence of vasodilatation, in contrast to the local effect on conjunctival vessels; in fact, a slight rise in blood pressure occurred in one subject, and is common after more marked exposure (13), presumably owing to stimulation of sympathetic ganglia or release of adrenalin. The effect on heart rate was slight. The effect on the gastrointestinal tract, sweat glands, central nervous system, and skeletal muscle was more pronounced.

Of the compounds studied, sarin had the greatest anticholinesterase activity in vitro; it is the most toxic to animals; and it produced its pharmacologic effects in man in the smallest doses. TEPP, DFP and parathion were less potent, in this order. There was a rough correlation between the inhibitory activity of these compounds

TABLE VII

Comparison between the anticholinesterase activity in vitro of sarin and other organic phosphate anticholinesterase compounds, and the effects in rats and man of the intramuscular (I.M.), intra-arterial (I.A.) and oral administration of these compounds*

\begin{tabular}{|c|c|c|c|c|c|c|c|c|c|}
\hline & \multirow{3}{*}{$\begin{array}{l}\text { In vitro } \\
\text { Ratio of } \\
\text { antiChE } \\
\text { activity }\end{array}$} & \multirow{2}{*}{\multicolumn{2}{|c|}{$\frac{\text { In rats }}{\begin{array}{c}\mathrm{LD}_{\mathrm{so}} \text { for rats } \\
(\mathrm{mg} . / \mathrm{Kg.})\end{array}}$}} & \multicolumn{6}{|c|}{ In man } \\
\hline & & & & \multicolumn{2}{|c|}{$\begin{array}{l}\text { Dose }(\mathrm{mg} . / \mathrm{Kg} .) \text { that } \\
\text { produced } 50 \% \text { depression } \\
\text { of RBC ChE }\end{array}$} & \multicolumn{2}{|c|}{$\begin{array}{l}\text { Dose }\left(m g . / K g_{g}\right) \text { that } \\
\text { produced moderate } \\
\text { symptoms }\end{array}$} & \multicolumn{2}{|c|}{$\begin{array}{l}\text { Estimated letha } \\
\text { dose }\left(m g . / K g_{.}\right)\end{array}$} \\
\hline & & I.M. & Oral & I.M. or I.A. & Oral & I.M. or I.A. & Oral & I.M. & Oral \\
\hline $\begin{array}{l}\text { Sarin } \\
\text { Tabun }\end{array}$ & $\begin{array}{c}1 \\
1 / 5\end{array}$ & $\begin{array}{l}0.17 \\
0.80\end{array}$ & $\begin{array}{l}0.6 \\
3.7\end{array}$ & 0.003 (I.A.) & 0.01 & 0.006 (I.A.) & 0.028 & 0.03 & 0.14 \\
\hline $\begin{array}{l}\text { TEPP } \\
\text { DFP }\end{array}$ & $\begin{array}{l}1 / 10 \\
1 / 100\end{array}$ & $\begin{array}{l}0.65 \\
1.8\end{array}$ & $\begin{array}{l}1.4 \\
6\end{array}$ & $\begin{array}{l}0.025 \text { (I.M.) } \\
0.07 \text { (I.M.) }\end{array}$ & $\begin{array}{l}0.10 \\
0.28\end{array}$ & $\begin{array}{l}0.083 \text { (I.M.) } \\
0.083 \text { (I.A.) }\end{array}$ & $\begin{array}{l}0.35 \\
0.32 ?\end{array}$ & $\begin{array}{l}0.38 \\
0.48\end{array}$ & $\begin{array}{l}1.7 \\
2.1\end{array}$ \\
\hline Parathion & $1 / 4,000$ & 6 & 10 & & & & & & \\
\hline
\end{tabular}

* See the following references: $\mathrm{LD}_{50}$ for rats of sarin (21), tabun (22), TEPP (23), DFP (24) and parathion (25). Doses that produced symptoms in man: TEPP (8) and DFP'(1). 
TABLE VIII Estimation of the amount of sarin required to produce 50 per cent inhibition of the blood and tissue cholinesterases of a
$70 \mathrm{Kg}$. man, and comparison with the oral and parenteral doses that produced 80 per cent inhibition of red blood cell cholinesterase in a $70 \mathrm{Kg}$. man

\begin{tabular}{|c|c|c|c|c|}
\hline \multirow[b]{2}{*}{ Body fluid or tissue } & \multirow[b]{2}{*}{$\begin{array}{l}\text { Total } \\
\text { weight } \\
\left(K K_{.}\right)\end{array}$} & \multicolumn{3}{|c|}{$\begin{array}{l}\mathrm{Mg} \text {. sarin required to produce } 50 \% \\
\text { inhibition of ChE activity of }\end{array}$} \\
\hline & & $\begin{array}{l}1 \mathrm{mg} \text {. of body } \\
\text { fluid or tissue } \\
\text { in vitro }\end{array}$ & $\begin{array}{l}\text { To } \\
\text { fluid } \\
\text { (cal }\end{array}$ & $\begin{array}{l}\text { body } \\
\text { tissue } \\
\text { lated) }\end{array}$ \\
\hline \multirow[t]{3}{*}{$\begin{array}{l}\text { Plasma } \\
\text { Red blood cells } \\
\text { Muscle (skeletal) } \\
\text { Cerebrum } \\
\text { Cerebellum } \\
\text { Thalamus } \\
\text { Pons, medulla, and spinal cord } \\
\text { Liver } \\
\text { Spleen } \\
\text { Kidneys } \\
\text { Pancreas } \\
\text { Heart }\end{array}$} & $\begin{array}{r}3.46 \\
2.84 \\
29.40 \\
1.15 \\
0.15 \\
0.02 \\
0.04 \\
1.40 \\
0.15 \\
0.26 \\
0.09 \\
0.31\end{array}$ & $\begin{array}{r}11.5 \times 10^{-9} \\
12.3 \times 10^{-9} \\
8.7 \times 10^{-9} \\
3.7 \times 10^{-9} \\
12.0 \times 10^{-9} \\
28.0 \times 10^{-9} \\
5.1 \times 10^{-9} \\
3.2 \times 10^{-9} \\
2.1 \times 10^{-9} \\
0.9 \times 10^{-9} \\
1.2 \times 10^{-9} \\
0.7 \times 10^{-9}\end{array}$ & & $\begin{array}{l}400 \\
349 \\
560 \\
042 \\
012 \\
006 \\
02 \\
003 \\
002 \\
001 \\
002\end{array}$ \\
\hline & & Total & & 424 \\
\hline & & \multicolumn{3}{|c|}{$\begin{array}{l}\text { Mg. sarin that produced } 50 \% \text { inhibition } \\
\text { of red blood cell ChE activity and } \\
40 \% \text { inhibition of plasma ChE }\end{array}$} \\
\hline Man & 70 & $\begin{array}{l}\text { After intra-art } \\
\text { After oral adm }\end{array}$ & min. & $\begin{array}{l}0.20 \\
0.70\end{array}$ \\
\hline
\end{tabular}

against the "specific" cholinesterases of red blood cells, muscle and brain, and the effective dose in animals and man, but the differences in the former were greater (Table VII). It is likely that the pharmacologic effects and toxicity of these compounds depend not only on the degree of their anticholinesterase activity, but also on their accessibility to the cholinesterase enzymes of the various effector tissues and on the time course of inhibition of these enzymes. Accessibility appears to be influenced by relative solubility in aqueous and lipoid media. Sarin, DFP and parathion, which are more soluble in lipoid than aqueous medium, have much greater central neural action than TEPP and neostigmine, which are more soluble in aqueous medium. DFP and parathion, especially the latter, are more toxic than might be expected from their anticholinesterase activity in vitro. This may be due in part to their greater partition coefficients in lipoid medium. In addition, parathion is converted in vivo into the oxygen analogue, a much more potent inhibitor of cholinesterase than the parent compound, which owes its anticholinesterase activity even in vitro to the presence of small amounts of the oxygen analogue or of the thio-ethyl or thio-phenyl isomers (26).
The time course of the inhibition of cholinesterase enzymes by anticholinesterase compounds depends on the rate of inhibition, reversibility of the inhibition, rate of restoration of the enzymes by the tissues, and rate of removal of free anticholinesterase compound. Sarin combines rapidly with cholinesterase enzymes in vitro, and after a short period of time this combination is not spontaneously reversible in vitro. In this regard sarin resembles DFP (1), and differs from TEPP (6) and parathion (19), which combine with cholinesterase in a reversible manner for several hours before the combination becomes "irreversible." The rate of restoration of the plasma and red blood cell enzymes in vivo following depression by sarin was similar to that following DFP (1), and is believed to reflect the rate of regeneration of plasma enzyme by the liver and of red cell enzyme in newly formed red blood cells, which are replaced at the rate of approximately one per cent per day. The rate of removal of free anticholinesterase compound is determined by the rates of hydrolysis, combination with cholinesterase enzymes and other proteins, other means of detoxification, and excretion. Sarin hydrolyzes slowly in dilute aqueous solutions at $37^{\circ} \mathrm{C}$. and $\mathrm{pH} 7$ over a period 
of approximately 24 hours. Hence this would be expected to have little influence on the action of sarin in vivo, which is exerted within an hour after administration. However, in the presence of tissue extracts, especially of liver, the hydrolysis of DFP is accelerated by the action of a hydrolytic enzyme (phosphofluorase) (27). It is not known if enzymatic hydrolysis of sarin occurs in man; the rates of disappearance, detoxification, and excretion of this compound have not been ascertained.

In order to estimate the proportion of orally or parenterally administered sarin which is hydrolyzed, detoxified or excreted before inactivating cholinesterase enzymes, the amount of sarin which might inhibit 50 per cent of the cholinesterase activity of the blood and other tissues of a $70 \mathrm{Kg}$. man was calculated (Table VIII). This figure was computed from the concentrations of sarin required to inhibit the enzyme activity of the various tissues in vitro, and from the estimated weight of these tissues. Since the sensitivities of red blood cell, muscle and brain cholinesterases to sarin in vitro were equal, and since oral or intramuscular administration to man of organic phosphate anticholinesterase compounds for short periods of time resulted in nearly as much depression of muscle and brain cholinesterases as of red blood cell enzyme (28), it has been assumed in the calculation that sarin is uniformly distributed in the blood and other tissues, even though it is more likely that the red blood cell enzyme is depressed to a somewhat greater degree than the cholinesterases of other tissues. The figure $(0.34 \mathrm{mg}$.) thus obtained for the amount of sarin that might be expected to produce 50 per cent inhibition of the cholinesterase activity of the blood and other tissues of a $70 \mathrm{Kg}$. man approximates the dose ( $0.21 \mathrm{mg}$.) that produced 50 per cent inhibition of red blood cell enzyme activity after intra-arterial administration. This suggests that intravascularly injected sarin is not hydrolyzed or detoxified to an appreciably greater extent in vivo than in vitro, and that it is not excreted prior to its reaction with cholinesterase. The calculations also suggest that about 75 per cent of the sarin that reacted with cholinesterase may have combined with muscle enzyme, about 22 per cent with plasma and red blood cell enzymes, and about 3 per cent with those of brain and liver. Although skeletal muscle has less cholinesterase activity per unit of weight than plasma, red blood cells, and some parts of the brain, and reacts with less sarin per unit of weight, its larger mass (42 per cent of body weight) would react with more sarin than all other tissues combined.

The observation that the amount of cholinesterase inhibited by a given dose of sarin is proportional to the level of enzyme activity suggests that there is a time limit for the reaction between cholinesterase and sarin. While the rate of the reaction would be expected to depend on the concentration of enzyme, the extent of the reaction would not, unless the reaction were limited by time. Such limitation could occur as a result of competitive removal of sarin by combination with proteins other than cholinesterase, by hydrolysis of sarin, and by competition with acetylcholine for cholinesterase. The first is probably most important. It is likely that the dose-effect relationship observed for the action of sarin on plasma and red blood cell cholinesterase activity may also be applicable to the effect of sarin on tissue cholinesterases and on the function of cholinergic effector organs. Riker and Wescoe (29) have demonstrated that the effect of intra-arterial DFP on the cholinesterase activity and response to electrical stimulation of the cat submaxillary gland is proportional to the level of enzyme activity.

The signs and symptoms produced by sarin are due to inhibition of the cholinesterase enzymes of the nervous system, muscle and secretory glands, and not to the coincident inhibition of the enzymes of the plasma and red blood cells. However, the activity of the latter enzymes may be used as a guide of some value in detecting systemic absorption of sarin, and even in estimating the amount absorbed, over a period of up to several days. Local ocular and respiratory (13) effects of sarin may occur without any inhibition of plasma and red blood cell cholinesterase activity, but systemic manifestations are invariably accompanied by depression of the activity of these enzymes. Following a single oral dose of sarin symptoms usually began coincident with depression of the plasma and red blood cell enzymes to approximately 34 to 22 per cent of original activity, and, following a single intravascular dose, to 60 and 50 per cent of original activity. The depression of these enzymes accompanying onset of 
symptoms was thus less marked following rapid than gradual absorption of sarin, probably because rapid absorption allows less "buffering" action of plasma and red blood cell cholinesterases and more ready access of the sarin to the enzymes of other tissues.

When the period of exposure to sarin was brief, as after a single dose, the degree of depression of plasma and red blood cell cholinesterases could be correlated roughly with the occurrence and severity of symptoms, and presumably with the degree of depression of the enzymes of the effector tissues. Observations following exposure to DFP (1-4), TEPP (6) and parathion (8) indicate that the organic phosphate anticholinesterase compounds exert their effects by depressing the cholinesterase activity of the tissues below a threshold at which changes in function begin, and that there is a relatively narrow margin between this threshold and the level of enzyme activity below which serious and even fatal functional alterations occur. The former threshold has been estimated to be about 50 per cent of normal activity, and the latter 10 to 20 per cent of normal (28).

When the period of exposure to sarin was longer, as after repeated doses at intervals of several hours or days, there was no correlation between the onset or severity of symptoms and the precise level of cholinesterase activity of the plasma and red blood cells, except that this was depressed considerably below normal. These observations, and the disappearance of symptoms before there was appreciable restoration of plasma and red blood cell enzyme, suggest that either the restoration of cholinesterase enzymes of the effector tissues following depression by sarin is more rapid than that of the plasma and red blood cells, or return of function is not dependent solely on recovery of tissue cholinesterase activity. The complete restoration of cholinesterases in the effector tissues probably requires several days, as indicated by increased susceptibility to the effects of sarin for more than 24 hours after the disappearance of symptoms, and persistence of electroencephalographic changes for as long as 18 days. Increased susceptibility to the effects of further exposure to sarin probably persists until the enzymes of the effector tissues have been restored. The cumulative effect of repeated exposure may result in the sudden appearance of severe symptoms, since the initial depression of activity may not be associated with warning symptoms.

It is likely that a single exposure of man to an organic phosphate anticholinesterase compound which was sufficient to reduce the enzyme of the red blood cells to between 1 and 5 per cent of original activity would lower the activity of other tissues below 10 per cent of normal, and would probably be lethal $(13,28)$. This "lethal" dose can be estimated by extrapolation of the observed dose-effect relationships for sarin (Figure 8), DFP (1) and TEPP (6) (Table VIII). Death due to these compounds, or to parathion, is caused by respiratory failure resulting from weakness of the muscles of respiration, central depression of respiration, and airway obstruction by bronchial and salivary secretions and to a lesser extent bronchoconstriction $(8,13)$. Treatment has relied upon the administration of large doses of atropine, alleviation of airway obstruction, and artificial respiration when needed. Atropine ameliorates the muscarine-like actions of the anticholinesterase compounds, and to a lesser extent the central neural effects, by inhibiting the action of acetylcholine at these sites. There is reduced susceptibility to the action of atropine in the presence of symptoms due to sarin, so that large doses may be administered before signs of atropinization appear (13). Atropine has no appreciable influence on muscular weakness. Until now there has been no practical means of accelerating recovery of cholinesterase activity and of muscular strength following depression by anticholinesterase compounds. Recent work, however, indicates that a number of oximes, including 2-pyridine aldoxime (2-PAM) and diacetyl monoxime (DAM), reverse cholinesterase inhibition (30) and neuromuscular block $(31,32)$ due to sarin, and accelerate the return of muscular strength.

\section{SUM MARY}

The administration of sarin to normal subjects resulted in muscarine-like, nicotine-like, and central nervous system signs and symptoms attributable to the inhibition of cholinesterase enzymes in the effector tissues, and resembling those produced by other organic phosphate anticholinesterase compounds. Of the compounds studied, sarin had the greatest anticholinesterase activity in vitro; it 
is the most toxic to animals; and it produced its pharmacologic effects in man in the smallest doses. TEPP, DFP and parathion were less potent, in this order. Sarin resembled DFP and parathion in being more soluble in lipoid than aqueous medium, and in producing marked central neural effects. It resembled DFP in producing "irreversible" inhibition of cholinesterase enzymes in vitro, and probably of plasma and red blood cell cholinesterase activity in vivo.

The relationship between the dose of sarin and the degree of depression of cholinesterase activity was the same in vitro as it was for plasma and red blood cell cholinesterase activity in vivo: the amount of enzyme inhibited by a given dose was proportional to the level of enzyme activity; each increment in dose inhibited the same fraction of enzyme; and the logarithm of the fraction that remained active decreased linearly with increasing dose. When sarin was administered in repeated doses at intervals of several hours to one day, the effect on cholinesterase activity and on symptoms was cumulative.

The oral administration of sarin resulted in systemic effects, and perhaps local gastrointestinal actions. Intra-arterial injection produced local and systemic effects. Conjunctival instillation resulted in local ocular changes. The effects of sarin were very prolonged, lasting from several hours after the smallest effective doses to several days after doses which produced moderate symptoms. The administration of atropine ameliorated the muscarine-like effects of sarin, and to a lesser extent the central neural effects, but had no influence on muscular weakness or fasciculations. There was reduced susceptibility to the action of atropine in the presence of symptoms due to sarin.

Following depression by sarin, the cholinesterase activity of the plasma was restored over a period of 40 days, at a rate compatible with the regeneration of enzyme by the liver, while that of the red blood cells was restored at the rate of one per cent per day, suggestive of regeneration of enzyme in newly formed red blood cells.

\section{REFERENCES}

1. Grob, D., Lilienthal, J. L., Jr., Harvey, A. M., and Jones, B. F. The administration of di-isoprophyl fluorophosphate (DFP) to man. I. Effect on plasma and erythrocyte cholinesterase; general systemic effects; use in study of hepatic function and erythropoiesis; and some properties of plasma cholinesterase. Johns Hopk. Hosp. Bull. 1947, 81, 217.

2. Grob, D., Lilienthal, J. L., Jr., and Harvey, A. M. The administration of di-isopropyl fluorophosphate (DFP) to man. II. Effect on intestinal motility and use in the treatment of abdominal distention. Johns Hopk. Hosp. Bull. 1947, 81, 245.

3. Grob, D., Harvey, A. M., Langworthy, O. R., and Lilienthal, J. L., Jr. The administration of diisopropyl fluorophosphate (DFP) to man. III. Effect on the central nervous system with special reference to the electrical activity of the brain. Johns Hopk. Hosp. Bull. 1947, 81, 257.

4. Harvey, A. M., Lilienthal, J. L., Jr., Grob, D., Jones, B. F., and Talbot, S. A. The administration of di-isopropyl fluorophosphate to man. IV. The effects on neuromuscular function in normal subjects and in myasthenia gravis. Johns Hopk. Hosp. Bull. 1947, 81, 267.

5. Leopold, I. H., and Comroe, J. H., Jr. Use of di-isopropyl fluorophosphate ("DFP") in treatment of glaucoma. Arch. Ophthal. (Chicago) 1946, 36, 1.

6. Grob, D., and Harvey, A. M. Observations on the effects of tetraethyl pyrophosphate (TEPP) in man, and on its use in the treatment of myasthenia gravis. Johns Hopk. Hosp. Bull. 1949, 84, 532.

7. Rider, J. A., Schulman, S., Richter, R. B., Moeller, H. C., and DuBois, K. P. Treatment of myasthenia gravis with octamethyl pyrophosphoramide: Preliminary report. J. Amer. med. Ass. 1951, 145, 967.

8. Grob, D., Garlick, W. L., and Harvey, A. M. The toxic effects in man of the anticholinesterase insecticide parathion ( $p$-nitrophenyl diethyl thionophosphate). Johns Hopk. Hosp. Bull. 1950, 87, 106.

9. Pharmacology and Toxicology of Certain Organic Phosphorus Insecticides, Report to the Council on Pharmacy and Chemistry of the Amer. Med. Ass. J. Amer. Med. Ass. 1950, 144, 104.

10. Grob, D. Uses and hazards of the organic phosphate anticholinesterase compounds. Ann. intern. Med. 1950, 32, 1229.

11. Wood, J. R. Chemical defense. J. Amer. med. Ass. 1951, 145, 1264.

12. Grob, D., and Harvey, A. M. The effects and treatment of nerve gas poisoning. Amer. J. Med. 1953, $14,52$.

13. Grob, D. The manifestations and treatment of poisoning due to nerve gas and other organic phosphate anticholinesterase compounds. Arch. intern. Med. 1956, 98, 221.

14. Grob, D. Manifestations and treatment of nerve gas poisoning in man. U. S. armed forces med. J. 1956, 7, 781. 
15. Krop, S., and Kunkel, A. M. Observations on pharmacology of the anticholinesterases sarin and tabun. Proc. Soc. exp. Biol. (N. Y.) 1954, 86, 530.

16. Holmstedt, B. Synthesis and pharmacology of dimethylamido-ethoxy-phosphoryl cyanide (tabun) together with a description of some allied anticholinesterase compounds containing the N-P bond. Acta physiol. scand. 1951, 25, Suppl. 90, 1.

17. Gehauf, B., Epstein, J., Wilson, G. B., Witten, B., Sass, S., Bauer, V. E., and Rueggeberg, W. H. C. Reaction for colorimetric estimation of some phosphorus compounds. Analyt. Chem. 1957, 29, 278.

18. Michel, H. O. An electrometric method for the determinatioin of red blood cell and plasma cholinesterase activity. J. Lab. clin. Med. 1949, 34, 1564.

19. Grob, D. The anticholinesterase activity in vitro of the insecticide parathion (p-nitrophenyl diethyl thionophosphate). Johns Hopk. Hosp. Bull. 1950, 87, 95.

20. Goldstein, A., Krayer, O., Root, M. A., Acheson, G. H., and Doherty, M. E. Plasma neostigmine levels and cholinesterase inhibition in dogs and myasthenic patients. J. Pharmacol. exp. Ther. 1949, 96, 56.

21. Askew, B. M. Oximes and hydroxamic acids as antidotes in anticholinesterase poisoning. Brit. J. Pharmacol. 1956, 11, 417.

22. Wilson, I. B., and Sondheimer, F. A specific antidote against lethal alkyl phosphate intoxication. $\mathrm{V}$. Antidotal properties. Arch. Biochem. 1957, 69, 468.

23. Mangun, G. H., and DuBois, K. P. Toxicity and mechanism of action of tetraethyl pyrophosphate. Fed. Proc. 1947, 6, 353.

24. Horton, R. G., Koelle, G. B., McNamara, B. P., and Pratt, H. J. The acute toxicity of di-isopropyl fluorophosphate. J. Pharmacol. exp. Ther. 1946, 87, 414.

25. DuBois, K. P., Doull, J., Salerno, P. R., and Coon, J. M. Studies on the toxicity and mechanism of action of p-nitrophenyl diethyl thionophosphate (parathion). J. Pharmacol. exp. Ther. 1949, 95, 79.

26. Diggle, W. M., and Gage, J. C. Cholinesterase inhibition in vitro by $\mathrm{O}$ O-diethyl O-P-nitrophenyl thiophosphate (parathion, E 605). Biochem. J. 1951, 49, 491.

27. Mazur, A. An enzyme in animal tissues capable of hydrolyzing the phosphorus-fluorine bond of alkyl fluorophosphates. J. biol. Chem. 1946, 164, 271.

28. Grob, D. Cholinesterase activity of the tissues of man determined post mortem: "Normal" values in infants and adults, and values in liver disease, myasthenia gravis, and after exposure to anticholinesterase compounds. Quart. Progress Report to Chemical Corps Medical Laboratories, Oct. 1, 1949.

29. Riker, W. F., and Wescoe, W. C. The relationship between cholinesterase inhibition and function in a neuroeffector system. J. Pharmacol. exp. Ther. 1949, 95, 515.

30. Wilson, I. B., and Ginsburg, S. Reactivation of acetylcholinesterase inhibited by alkylphosphates. Arch. Biochem. 1955, 54, 569.

31. Grob, D., and Johns, R. J. Use of oximes in the treatment of intoxication by anticholinesterase compounds in normal subjects. Amer. J. Med. 1958. In press.

32. Grob, D., and Johns, R. J. Use of oximes in the treatment of intoxication by anticholinesterase compounds in patients with myasthenia gravis. Amer. J. Med. 1958. In press. 